Quebec Cooperative Study of

Friedreich's Ataxia

\title{
Oxygen Transport in Patients with Friedreich's Ataxia
}

\author{
M. A. BUREAU, Y. BERTHIAUME, R. BEGIN, D. SHAPCOTT, B. LEMIEUX AND M. COTE
}

SUMMARY: The hypothesis that an abnormal oxygen-hemoglobin dissociation curve is a primary or a secondary defect in patients with Friedreich's ataxia was investigated in 12 subjects with this disease. Hemoglobin and P50 were measured and compared with age and sex matched controls. The mean hemoglobin concentration was $14.2 \mathrm{~g} \%$ and the P50 was 26.25 torr for the patients and 13.8 $g \%$ and 26.27 torr in the controls. These results indicate that the oxygen transport system is normal in this disease and likely exclude an abnormal oxygen dissociation curve as a primary or a secondary factor in the pathophysiology of the cardiomyopathy and the neuromyopathy found in this disease.

RÉSUMÉ: Nous avons étudié chez 12 patients souffrant d'ataxie de Friedreich l'hypothèse que la courbe de dissociation oxygène-hémoglobine soit anormale dans cette maladie, de façon primaire ou secondaire. L'hémoglobine et le P50 furent mesurés et comparés à ceux de contrôles apparillés pour l'âge et le sexe. La concentration moyenne d'hémoglobine fut de $14.2 \mathrm{~g} \%$ chez les patients et $13.8 \mathrm{~g} \%$ chez les contrôles. Pour le P50, les valeurs étaient de 26.25 torr et 26.27 torr respectivement. Ces résultats indiquent que le système de transport de l'oxygène est normal dans celle maladie. Il est donc très peu probable qu'une courbe de dissociation oxygène-hémoglobine anormale soit un facteur primaire ou secondaire dans la pathophysiologie de la cardiomyopathie et de la neuromyopathie trouvée dans cette maladie.

From Le Centre Hospitalier Universitaire de I'Université de Sherbrooke.

Reprint requests for the complete supplement on Friedreich's Ataxia (Phase Two, Part One) to: Dr. André Barbeau, Clinical Research Institute of Montreal, 110 Pine Avenue West, Montreal, Quebec, Canada H2W IR7.

\section{INTRODUCTION}

In the Quebec Cooperative Study which had been designed as a systematic approach to investigate Friedreich's ataxia, it appeared necessary to evaluate the oxygen transport system as a possible primary or secondary abnormality contributing to the cardiomyopathy and the neuromyopathy of this disease. This hypothesis seemed reasonable for two reasons: firstly, the hypertrophic cardiomyopathy (Côté et al., 1976) and the myocardial fibrosis (Sanchez-Casis et al., 1976) found in the majority of these patients could be explained only in part by the premature coronary artery disease found at autopsy in such patients; the second observation which suggested an abnormality in the oxygen-hemoglobin dissociation curve is related to the abnormal pulmonary function seen in patients with Friedreich's ataxia. These pulmonary abnormalities were reported, from our laboratory, to be a mild degree of hypoxia with a low diffusing capacity and a progressive fall in total lung capacity, in vital capacity, and a late decrease in residual volume and functional residual capacity (Bureau et al., 1976). Such abnormalities in another respiratory disease have been associated with alteration of the $\mathrm{Hb}-\mathrm{O}_{2}$ dissociation curves (Weiss et al., 1971). The present study was instituted to test the hypothesis of an abnormal $\mathrm{Hb}-\mathrm{O}_{2}$ dissociation curve as a primary or secondary defect in Friedreich's ataxia.

\section{MATERIALS AND METHODS}

The oxygen transport system was studied in 12 patients with typical Friedreich's ataxia as previously de- scribed (Geoffroy et al., 1976). The results for this group were compared with those of 12 age and sex matched normal volunteers who constituted part of our pool of 21 normals.

The study of the oxygen transport system consisted of the determination of hemoglobin $(\mathrm{Hb})$, oxygen tension af $50 \%$ of $\mathrm{Hb}$ saturation $\left(\mathrm{P}_{50}\right)$ and oxygen concentration at $50 \%$ of $\mathrm{Hb}$ saturation. $\mathrm{Hb}, \mathrm{Hb}$ saturation and oxygen content were measured with the I.L. 280 oximeter. Pso was determined on venous blood at $37^{\prime}$, pH 7.40 and $P_{c o 2}$ of 40 torr.

From each patient and control 4 $\mathrm{ml}$ of heparinized venous blood 'was withdrawn and immediately subjected to the following analysis: first, the $\mathrm{Hb}$ concentration was measured, then the blood was equilibrated (I.L. 237 tonometer) for 10 minutes (as was found to be necessary) at three levels of oxygen concentration; $4.0 \%, 3.5 \%$ and $3 \%$ at a constant $\mathrm{CO}_{2}$ concentration of $5.6 \%$, and $\mathrm{Hb}$ saturation was determined at each level to give one point on the $\mathrm{Hb}-\mathrm{O}_{2}$ dissociation curve. The three points obtained were used to determine the $P_{50}$, and since these points were in the middle of the sigmoid curve they were in almost perfect alignment, which made it easy to establish the $\mathrm{P}_{50}$ on the $\mathrm{Hb}-\mathrm{O}_{2}$ saturation and $\mathrm{P}_{02}$ graph. Although the saturation was measured in blood with a $\mathrm{P}_{\mathrm{co} 2}$ value in the vicinity of 40 torr, the $\mathrm{pH}$ varied from 7.415 to 7.350 and so a slight correction of $\mathrm{P}_{02}$ (using the pH- $\mathrm{P}_{02}$ nomogram) was necessary to obtain the $\mathrm{P}_{50}$ at a standard $\mathrm{pH}$ of 7.40. The gas mixing apparatus was the I.L. 208-1 and the I.L. 208-2.

At each level of oxygen tension one milliliter of blood was withdrawn from the tonometer and 
analysed successively for $\mathrm{P}_{02}, \mathrm{P}_{\mathrm{co} 2}$, $\mathrm{pH}$ (using the Corning 165 blood gas apparatus), and then the $\mathrm{Hb}-\mathrm{O}_{2}$ saturation was measured with the I.L. 282 oximeter, and finally the blood gas measurements were repeated. The Corning 165 blood gas apparatus was calibrated before each measurement. In a preliminary experiment to verify the precision of the I.L. 282 oximeter for low saturation of $\mathrm{Hb}$, it was established that for each level of $\mathrm{P}_{02}$ a single determination of $\mathrm{Hb}$ saturation was adequate for this experiment.

\section{RESULTS}

Figure 1 gives the values of $P_{50}$ (at sea level) for our control subjects and in patients with Friedreich's ataxia. For the normals (mean age $17.8 \pm 1.7$ years), the mean $P_{50}$ was 26.27 torr with a standard error of 0.25 torr, their $\mathrm{Hb}$ was $13.8 \pm 0.4$ $\mathrm{g} \%$, their oxygen content at $50 \%$ saturation was $9.27 \pm 2.1 \mathrm{ml}$. Patients with Friedreich's (mean age $17.5 \pm 1.7$ years) had a mean $\mathrm{P}_{50}$ of $26.25 \pm 0.21$ torr, a mean $\mathrm{Hb}$ of $14.2 \pm$ $0.2 \mathrm{~g} \%$ and a mean oxygen content at $50 \%$ saturation of $9.54 \pm 0.18 \mathrm{ml}$. These values did not differ from those of the matched control group, nor did the slope and $y$ intercept of the relationship between $P_{50}$ and hemoglobin (Fig. 2).

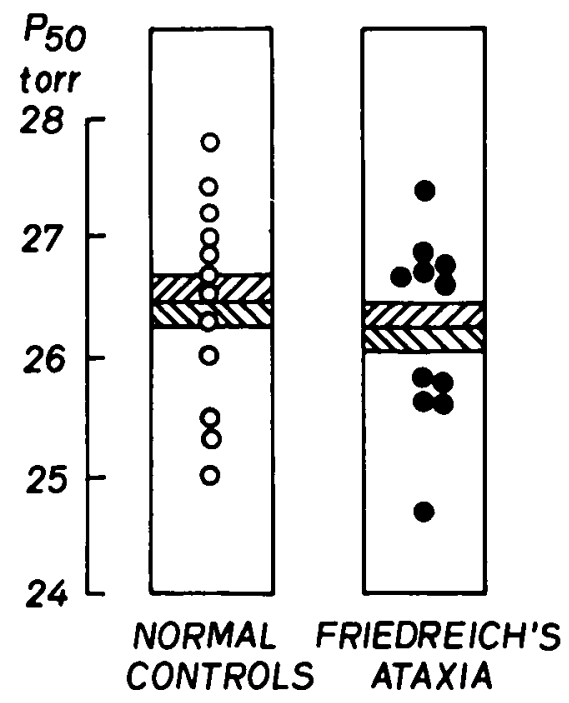

Figure $1-\mathrm{P}_{50}$ in normal controls and in patients with Friedreich's ataxia. The solid line is the mean $\mathrm{P}_{50}=$ S.E.M.

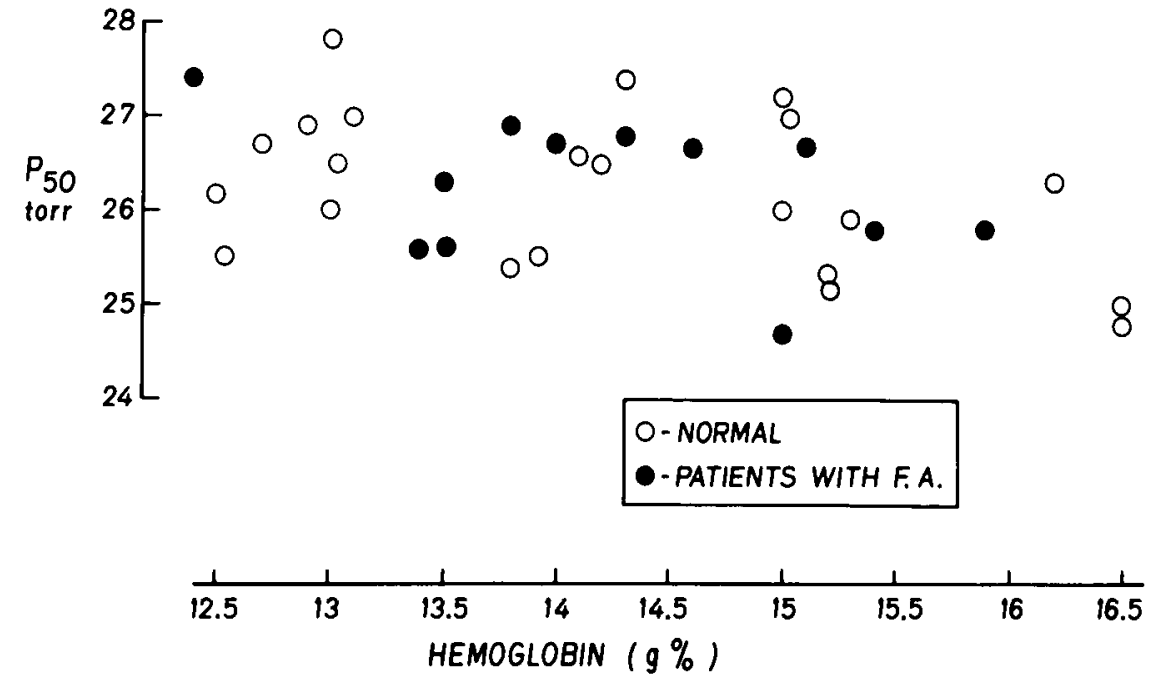

Figure 2-The inverse relationship of P50 hemoglobin concentration. The slope and y intercept for the patients $(-0.345,31,185)$ did not differ significantly from the controls $(-0.255,29.86)$.

\section{DISCUSSION}

The $\mathrm{P}_{s 0}$ in our normal control subjects was 26.27 torr, a value which is comparable to that obtained in normal non-smokers by other investigators (Severinghaus, 1971). Furthermore, as previously noted by Torrance et al. (1970) and by Edwards and Canon (1972), we found a significant inverse relationship between the $\mathrm{P}_{50}$ and the $\mathrm{Hb}$ concentration, confirming that the shift to the right in the $\mathrm{Hb}-\mathrm{O}_{2}$ dissociation curve is an important and sensitive mechanism for compensation in maintaining normal oxygen transport, even within the normal range of hemoglobin. This increase in $\mathrm{P}_{50}$ with lower $\mathrm{Hb}$ levels could apparently be induced by an increase of 2-3 diphosphoglycerate in the red blood cells. In our group of patients with Friedreich's ataxia who had been reported to have pulmonary abnormalities (Bureau et al., 1976), one would have predicted at least a secondary change in $\mathrm{P}_{50}$ in an attempt to compensate for their cardiopulmonary disease, as has been reported in other milk pulmonary diseases (Wiess et al., 1971). However, the Pso was normal for our patients with Friedreich's ataxia, which establishes that they had a normal oxygen transport system. One must conclude that the unloading of oxygen at the muscle and the myocardium is carried out in the normal way and so the degenerative disease is not caused nor compensated by changes in the oxygen transport system.

The absence of the expected changes in the $\mathrm{Hb}-\mathrm{O}_{2}$ dissociation curve raises the question: can patients with Friedreich's ataxia produce the 2-3 diphosphoglycerate during red blood cell glycolysis to compensate for their hypoxia? To assess this question, it would be necessary to measure Pso and 2-3 diphosphoglycerate in severely affected patients having a severe hypoxia. In the present study the mean degree of hypoxia was not severe enough to test this possibility (Bureau et al., 1976).

Furthermore, this observation is an extension of our knowledge of the adaptive mechanisms in response to tissue hypoxia. It has been well established that severe tissue hypoxia increases the red blood cell 2-3 d. p.g., which in turn causes a shift to the right of the $\mathrm{Hb}-\mathrm{O}_{2}$ dissociation curve, which favors the unloading of oxygen from $\mathrm{Hb}$ to the tissue, this being an important compensation mechanism in patients with systemic hypoxia due to chronic lung disease (Edwards et al., 1968). More recently, in milder systemic hypoxemia (mean Pa02: $72.1 \pm 13.6 \mathrm{~mm} \mathrm{Hg}$ ) found in patients with restrictive pulmonary disease, a similar shift to 
the right of the $\mathrm{Hb}-\mathrm{O}_{2}$ dissociation curve was observed, but without a simultaneous increase of 2-3 d.p.g. or polycythemia, suggesting that the $P_{s 0}$ was a more sensitive index of oxygen-Hb affinity (Weiss et al., 1971).

Our control subjects, like those of Weiss et al. (1971), had a normal Pso at a $\mathrm{Pa}_{02}$ of about $90 \mathrm{~mm} \mathrm{Hg}$. Our finding of a normal $\mathrm{P}_{50}$ in the presence of mild hypoxia ( $\mathrm{Pan} 281.2 \pm 1.9$ $\mathrm{mm} \mathrm{Hg}$ ) in Friedreich's ataxia patients suggests that the shift to the right of the $\mathrm{Hb}-\mathrm{O}_{2}$ dissociation curve is initiated only when the Panz is between 70 and $80 \mathrm{~mm} \mathrm{Hg}$, other factors being negligible.

Thus, the lung volume changes and mild hypoxia observed in Friedreich's ataxia at an early stage do not alter the $\mathrm{Hb}-\mathrm{O}_{2}$ dissociation curve and do not contribute at this early stage to the myocardial fibrosis and degeneration observed later in the disease.

\section{ACKNOWLEDGMENTS}

These studies were carried out with the help of grants from l'Association Canadienne de l'Ataxie de Friedreich and The Medical Research Council of Canada [MA-5726]. The authors thank Miss S. Gariépy for typing the manuscript.

\section{REFERENCES}

BUREAU, M. A., NGASSAM, P., LEMIEUX, B. and TRIAS, A. (1976). Pulmonary function in Friedreich's ataxia. Can. J. Neurol. Sci., 3, 343-348.

COTE, M., DAVIGNON, A., ELIAS, G., SOLIGNAC, A., GEOFFROY, G., LEMIEUX, B. and BARBEAU, A. (1976). Hemodynamic findings in Friedreich's ataxia. Can. J. Neurol. Sci., 3, 333-342.

EDWARDS, M. J. and CANON, B. (1972). Oxygen transport during erythropoetic response to moderate blood loss. N. Engl. J. Med., 287, 115-119.

EDWARDS, M. J., NOVY, M. J., WALTERS, C. L. and METCALF, E. J. (1968). Improved oxygen release: an adaptation of mature cells to hypoxia. J. Clin. Invest., 47, 1851-1853.

GEOFFROY, G., BARBEAU, A., BRETON, G., LEMIEUX, B., AUBE, M., LEGER, C. and BOUCHARD, J. P. (1976). Clinical description and roentgenologic evaluation of patient with Friedreich's ataxia. Can. J. Neurol. Sci., 3, 279-286.

SANCHEZ-CASES, G., COTE $M$. and BARBEAU, A. (1976). Pathology of the heart in Friedreich's ataxia: review of the literature and report of one case. Can. J. Neurol. Sci., 3, 349-354.

SEVERINGHAUS, J. W. (1971). Blood oxygen dissociation line chart: man. In: Altman, P. C. and Dittmer, D. S. (eds) Respiration and circulation, Bethesda, Md., Federation of American Societies for Experimental Biology, pp. 204-206.

TORRANCE, J., JACOBS, P., RESTREPO, A., ESCHBACK, J., LENTANT, C. and FINCH, C. A. (1970). Intraerythrocytic adaptation to anemia. New Engl. J. Med., 283, 165-169.

WEISS, E. B., SLAWSKY, P. and DESFORGES, J. F. (1971). Oxyhemoglobin affinity in chronic pulmonary granulo matosis (Sarcoidosis) and fibrosis. Am. Rev. Resp. Dis., 104, 694-702. 